\title{
IMPLICATIONS OF CROSS LIMITATIONS IN ILLINOIS
}

\begin{abstract}
Homer F. Carey*
TO THE lawyer, and even the judge, without long experience with future interest problems the implication of cross limitations is something of a mystery. Very frequently the practitioner insists they exist in a particular case because their presence would give the desired result, although he does not know either the theoretical or practical operations of this property mechanism. Advocacy, after all, is concerned with results, but it is no doubt true that it would be made more effective by a more thorough understanding.
\end{abstract}

\section{A. INTERMEDIATE ITMITATIONS}

Sometimes when cross limitations could properly be raised they are passed over unnoticed by judges and lawyers alike. This happened in Cheney v. Teese. In that case the testator after giving legal life estates in certain lands to his two surviving daughters devised the remainder in fee to his grandchildren "share and share alike, to take possession only after the death of my said daughters." children and the question upon the construction of the will was whether the surviving daughter took the whole land for her life or whether the enjoyment of the half interest enjoyed by the deceased daughter passed to others. The first point made by the court was that upon a proper interpretation of this will the grandchildren could not be let into possession of

* Professor of Law, Northwestern University School of Law.

${ }^{x}$ I08 Ill. 473 (1884). This omission was observed in a later case, Addicks v. Addicks, 266 III. 349,356 and 357, I07 N.E. 580 (I9r5).

${ }^{2}$ The typical case to be considered in the first part of this article involves a gift of either legal or equitable interests in either real or personal property by a testator to his two children, $A$ and $B$, for their lives with a remainder upon their decease to their children.

So that the reader, unfamiliar with this field of learning, may understand the problem, this explanatory note is offered. The situation which gives rise to the problem invariably is the death of either A or B leaving children. The surviving life tenant claims the whole life estate and the children of the deceased life tenant claim absolute ownership of half of the property. If there are no cross limitations by implication, such children prevail; if there are such cross limitations they do not. If cross limitations exist and if they were to be translated, the limitations would go like this: To A for his life with remainder to him for his life of B's share upon his (B's) death; to B for his life with remainder to him for his life of A's share upon his (A's) death. Where there are more than two life tenants the problem is the same. The only effect of increasing them is to increase the number of cross limitations. 
the land until after the death of both daughters. The intention was to grant to the daughters the full use of the land between the time of the testator's death and the death of the last daughter. On an intention of this kind the court should have held that the surviving daughter took the whole land for her life upon the theory that each daughter had a vested remainder for life in the share given to the other. But it held that since there could be no joint tenancy in land under the statutes then in force the surviving daughter could not enjoy the whole. Each daughter must be regarded as having an estate pur autre vie in her share of the land during the life of the survivor. Thus the deceased daughter had a life estate for the life of the surviving daughter which, so the court held, passed to said deceased daughter's heirs or devisees. ${ }^{3}$ The latter were entitled to the enjoyment of half of the land pending the vesting of possession in the grandchildren. It should be noticed in passing that it was not at all necessary for the court to have held that the remainders should not be admitted to possession until the death of both daughters, for the will postponed them until "only after the death of my said daughters." In reaching the conclusion that both daughters had to die before the remaindermen were entitled to possession, was the court influenced by the fact that the remainder was to the testator's "grandchildren" rather than in terms to the children of his daughters and, perhaps also because it was not simply a remainder to "grandchildren" but was to them "share and share alike"? At this point it is proper to ask whether a rule of construction in favor of per capita distribution to a class following a gift to two or more persons as tenants in common of limited interests in property operates to compel a postponement of the enjoyment of the future interest until the death of the last tenant in common. If it does, then, the situation for the implication of cross limitations exists. A question of similar import is whether a rule of construction in favor of stirpital distribution to a class in cases of this character operates to compel a letting in of the future interest at different times, i.e., upon the death of each tenant in common, with the result that there is no room for the implication of anything as far as the words go because there is no hiatus between the gift of the particular estate and the future interest. These questions are pertinent in the common case in which the letting in of the future interest is not expressly postponed until the death of the last of the tenants in common.

In the next case ${ }^{4}$ before the Illinois supreme court the testator after

3 In Bullard v. Suedmeier, 29I Ill. 400, I26 N.E. Ir 7 ( $x_{920}$ ) it was held that an estate of this kind reserved to a grantor was not real property but personal property.

4 Fussey v. White, II3 IIl. 637 (1885). 
providing for his wife for her life directed the residuary estate "be held for the use and benefit of my said children, share and share alike, .... and that upon their decease their children to have and receive one-half part or portion thereof. ...." The testator's two children, a son and daughter, survived him and also their mother. Upon the death of the son leaving children the question of participation by the children and their aunt in the corpus of the trust arose. The supreme court directed its attention to the question whether, as it has been put in the English cases, ${ }^{5}$ the whole estate should go over together or fractionally and at different times. It concluded that "upon their decease" a gift to "their children" means upon the respective deaths of the life tenants and that the children of each life tenant take per stirpes. "In such case the court will not construe the will as postponing the distribution of every part until the death of the surviving tenant for life, unless an intention so to do is clearly indicated." In reaching this result the court followed the English authorities. ${ }^{6}$ One wonders how far the conclusion reached in the sentence quoted above is founded upon the absence of words expressly postponing the letting in of the remainder and how far it is based upon the rule of stirpital division of the remainder. The briefs of counsel in the case show that great stress was placed upon the stirpital or per capita division of the remainder. It is entirely possible that the division of a remainder per stirpes or per capita ought to have no bearing upon the problem and that the common phrases "at their death" (referring to the life tenants) and "to their children" ought to impel a result by their own inherent force.

For a clearer understanding of this problem a study of several Massachusetts cases may be profitable. In Loring $v$. Coolidge, ${ }^{7}$ the court was called upon to construe a will which created a trust to pay "the income .... equally to my brother . . . . and my sister .... during their natural lives, and at their death the principal I give to my nephews and nieces then living." The brother having died, the nephews and nieces claimed that the estate should be divided, and one-half should be presently distributed to them. The court held that the principal was given:

as one fund to a single class, consisting of nephews and nieces, per capita. The time for this gift to take effect, and for determining what individuals are to constitute this class, is fixed as a single event. 'At their death,' as a point of time, is the date when

$s$ See for instance Maden v. Taylor, 45 L.J.N.S. 569 (1876).

${ }^{6}$ Willes v. Douglas, $5^{\circ}$ Eng. Rep. 499 (1847); Sarel v. Sarel, 53 Eng. Rep. $34,(x 856)$; Turner v. Whittacker, 53 Eng. Rep. 77 ( 1856 ); Taniere v. Peackes, 57 Eng. Rep. 392 (1825); Arrow v. Mellish, 63 Eng. Rep. I102 ( 1847 ); Wills v. Wills, L. R. 20 Eq. 342 ( 1875 ).

799 Mass. IgI (x868). 
both shall have deceased. These words may be, and sometimes are, construed distributively, when the nature or order of the sequent dispositions is such as to require it; as when the subsequent interests are given, per stirpes, to the children or other representatives respectively of those (not husband and wife) who are to enjoy the income during their lives. [Here follows citation of English cases already referred to herein]. But in such cases the interpretation of the ambiguous term is governed by the apparent intent that the subsequent interests shall pass separately to each class, as succeeding to the share of the parent or other cestui que trust for life whom they respectively represent.

This rather lengthy quotation is valuable since it contains as clear a statement of the rationale of the decisions as can be found in the books. The court then continues to justify its determination that the gift in remainder to the surviving nephews and nieces was a gift to a single class per capita. The gift was not to the class "as representatives of the brother and sister" because there was "no reference to their relation to the brother and sister, but only to their relation to the testatrix." Moreover the fact was that neither life beneficiary had any children. The court having reached the conclusion that the whole fund should go over at one time to a single class had next to answer the question of what should be done with one-half of the income in the meantime, because there was no gift over of income. Of course it was in this that the nephews and nieces found their strongest argument for a present division of half of the corpus and they were especially insistent that the gift of income to the two life tenants "equally" could never be held to permit the survivor to take it all.

If the directions to pay the income "equally" were to be given a strict construction, the trust, said the court, would have to end after the death of one beneficiary. But the trust could not be ended then when in fact there was no intent to break in upon the corpus at all until the death of both beneficiaries and since there was "no other party to claim an interest in the income .... [formerly payable to the deceased life tenant] .... it seems to follow that the entire income should be paid to the survivor."

It should be noted that nowhere in the whole opinion is there any mention of an implied gift, or even an implication of cross limitations. The dominant note of the case is the necessity for a single distribution at a single point of time predicated upon the necessity of "determining what individuals are to constitute the class," by reference thereto. The surviving life tenant is given the whole income because of the inability of the court to find a better disposition to make of it rather than upon some logical theory of a gift of it all to him in the event which had happened. It is in fact a solution of despair. 
The next important case ${ }^{8}$ bearing upon this problem came before $\mathrm{Mr}$. Justice Holmes for solution. Here the testator gave his residuary estate to his two children for life, "and at their decease the said real and personal estate shall revert to their children. ...." One of the children had three children; the other had five. Upon the death of the last of the two children of the testator the question arose as to whether the remaindermen would participate per stirpes or per capita. The court first refers to the English cases already referred to herein and concludes that the reason for a stirpital division of a remainder limited to "children" of tenants in common upon "their decease" (life tenant's) must be "inferred from the fact that it [the corpus] will go over immediately" upon the death of each. life tenant. Then comes a reference to the earlier Massachusetts case.

Perhaps this court has gone further than the English courts would, in reading "at their decease" as meaning "when all the life tenants shall have died," rather than "as they respectively die," Loring v. Coolidge, although in that case the limitation over was not to children of the life tenants. But, when this interpretation is adopted, the reason for the English rule ceases, because the whole fund goes over together, instead of in separate shares at different times.

A consideration of these two cases together presents a curious situation. In the first the assumed necessity for a per capita division in remainder impelled the court to declare that no remainderman should be let in until all the life tenants had died. In the second, when the question of how remaindermen should share was presented, what in the first was a consequence of a mode of division of a remainder becomes a cause for that same rule of division. Thus we have a reversible equation. If in the class of cases already considered the remaindermen take per capita none can be let in until all the life tenants are dead and upon the death of each life tenant the surviving life tenant or life tenants enjoy the property; if the remaindermen cannot be let in until all the life tenants are dead they take per capita and not per stirpes and upon the death of each life tenant the survivor or survivors enjoy the property. In this situation it is difficult to distinguish the cause from the effect and since the words used are ambiguous it is as easy to break in upon the circle at one point as another. In a late case $^{9}$ the Massachusetts court when confronted with the question whether a trust fund should be divided per stirpes or per capita between

${ }^{8}$ Dole v. Keyes, 143 Mass. 237,9 N.E. 625 ( 1887 ).

9 Gleason v. Hastings, 278 Mass. 409 , I80 N.E. I29 (I932). In recent years the Massachusetts courts seem to have departed very decidedly from their earlier rulings in holding that a limitation to "issue in equal shares" results in a per capita division. See Cammann v. Abbe, 258 Mass. 427 , 155 N.E. $43^{8}$ (I927). Cf. Hall v. Hall, I40 Mass. 267,2 N.E. 7or (1885) by Holmes, J., and 20 Col. Law Rev. 7r4 (rg20). 
the "issue" of three life tenants referred to the reasoning of Mr. Justice Holmes. "There would be little reason for keeping a trust fund undivided until that time [death of all life tenants] if distribution was then to be made according to stocks. See Dole v. Keyes."

The next case in Illinois in which the question of the implication of cross limitations arose in a fact situation like that thus far considered, i.e., gift to two or more in common for life with remainder over-was Addicks $v$. Addicks. ${ }^{\text {To }}$ Here the testator left surviving him a widow and four children, two sons and two daughters. By the third clause of his will he gave his widow a life estate in certain acreage and by the tenth clause he gave the same land to his two sons for their lives subject to the life estate in their mother. ". . . I give, devise and bequeath to my two sons, George B. Addicks and Charles S. Addicks, to share alike the rent and income of the said tract of land above described during their natural lives, subject, however, to the life estate of my said wife. After the death of my sons, George B. Addicks and Charles S. Addicks, said tract of land shall be sold and the proceeds thereof shall be equally divided between all of my grandchildren, share and share alike." After the death of the widow and their father, George B. Addicks, his children contended that they were entitled to half of the property during the life of Charles S. Addicks. They contended that their father and Charles $S$. Addicks each took in his respective share a life estate for not only his life but that of the surviving life tenant and that this interest passed to them from their father. In other words they claimed that their father had an estate pur autre vie. It is obvious that this claim was founded upon the ruling in Cheney $v$. Teese. ${ }^{\mathrm{II}}$ It was abundantly clear that if the rule of that case was sound it ought to work here. It should be noted first, that the children of the deceased life tenant did not claim that they took per stirpes and, secondly, they did not claim, that the remainder as to half of the property fell into possession at their father's death: "The parties are agreed .... that it appears from the will the intention of the testator was that the land was not to be sold and the proceeds divided among his grandchildren until after the death of George and Charles." Clearly, the testator must have contemplated one sale and one division of the proceeds among his grandchildren per capita. Under these circumstances the case is very clearly one for the implication of cross remainders for life and this was what the court held. The court cites and approves the first of the Massachusetts cases above discussed, Loring $v$. Coolidge; it disapproves of Cheney v. Teese.

${ }^{20} 266$ III. 349 , Io7 N.E. 580 (I9I5).

II I08 Ill. 473 (I884). 
In the third $\mathrm{d}^{\mathrm{x} 2}$ case of the same general character in Tllinois the testator left his residuary estate, consisting principally of land, in trust for his three children equally for their lives and "At the death of all my said children herein named, I hereby will, devise and bequeath said real estate and personal property to my grandchildren then living, the child or children or each of my said daughters or son taking the same part thereof as his, her or their mother or father would have taken if I had died intestate." Here there is a will which postpones the remainder in enjoyment until all the life tenants have died and which, at the same time explicitly gives the remainder per stirpes. This was clearly a case for the implication of cross limitations and the court so held. The argument against cross limitation was founded in some measure upon the stirpital division of the remainder as operating to effect a fractional division of the corpus at different times. This argument required the word "all" to be suppressed on construction or that it be read to mean "any." The court rejects the point. "While counsel for plaintiffs in error attempt to distinguish this case from the Addicks case, we think, in principle, there is no distinction. In the Addicks case the remainder in fee passed to the grandchildren per capita and not per stirpes, but that would not affect the estate arising by implication in the first takers." The last clause is obviously true in relation to a case in which the will clearly postpones division until the death of all the life tenants, but that assertion cannot be made with the same confidence in a case in which there is wanting all definiteness in this important and controlling particular.

The fourth Illinois case discussing the implication of cross limitations in a fact situation similar to those previously considered is Randolph $v$. Wilkinson. ${ }^{13}$ Here the testator after providing for his wife for her life gave all of his property to his four children and one grandchild "and the survivors of them during their natural lives and for twenty years after the death of my last child and grandchild now living. . . ." At the termination of the twenty year period he gave the property to the descendants of his children and grandchild per stirpes. The court was called upon to determine the effect of a conveyance by the five devisees of all of their interest in one of the five shares of the devised lands upon the destructibility of the ultimate future interests. The latter the court held to be contingent remainders and consequently destructible. In passing upon the dispositions of this complicated will the court declared that each of the five devisees had cross remainders "expressly raised by the provisions

I2 Kramer v. Sangamon Loan Co., 293 Ill. 553, I27 N.E. 877 (I920).

${ }_{3} 294$ III. 508, 128 N.E. 525 (1920). 
of the will" and that such remainders "would be implied if the language of the will did not authorize the same by express language." The devise over of the estate in solido only after the expiration of twenty years from the death of the last of the five devisees produced this result. The case is singularly unusual on its facts in that the implications of cross limitations are of a different duration and of a different character than in the cases heretofore considered. But the basic feature in them all is the implication of cross limitation, if they are to be implied at all, for a period following the death of one or more takers of limited interest in the property and extending to the time when the future interests are let in. ${ }^{\mathrm{I}}$

The fifth and last reported decision bearing upon this problem by the courts of Mllinois is Whittaker 0 . Porter. ${ }^{\mathrm{x}}$ The separate wills of both husband and wife, the former disposing of 400 acres and the later of 560 acres of land, were construed in a partition suit. The husband's will provided: "Upon the death of my wife, Elizabeth, I direct that the income from all said real estate be equally divided between my daughters, Cora $B$. Wittaker, of Brumfield, Ill., and Fannie E. Porter, of Hume, and upon the death of my daughters above mentioned, said property is to become the property of their children to have and to hold as they deem best, and the property to be divided equally between the said children of Cora B. Whittaker and Fannie E. Porter." The wife's will, while not identical, could not be said to have a different legal effect upon the problem here considered. Mrs. Whittaker had two children and Mrs. Porter had six when the former commenced a partition suit against the latter involving all the lands passing under both wills. The Whittaker group naturally took the position that each daughter had a life interest in a half with a remainder to her children upon her death, while the Porter group contended for cross limitations for life with a per capita division upon the death of the last surviving daughter. The court held with the former and followed a group of English authorities hereinbefore referred to-authorities cited and rejected by Mr. Justice Holmes in Dole v. Keyes. ${ }^{16}$ The court invoked the rule so frequently announced in the English cases and in English texts on Wills, that a gift to two or more as tenants in common for life with a gift over at, after, or upon their death or deaths to their children must be held to direct a division in remainder in fractional amounts and at different times, i.e., upon the death of each life tenant, respectively. The children of each life tenant receive that share of the property from which

${ }^{14}$ In some cases the implied cross limitation is of a general estate tail. Doe v. Webb, I Taunt. 235, 127 Eng. Rep. 823 (I808).

is 32 I Il. 368 , I5I N.E. 905 (r926).

${ }^{36}$ Note 7 supra. 
the parent received the income or had the use of while he lived. This is what has been uniformly spoken of in the books as a division per stirpes and on this account the following remarks of the court are not in harmony with what has become standard by way of definition. "Since the wills devise an undivided half of the land to each daughter for life with a remainder in fee after each daughter's life estate to her children, argument as to cross-remainders or as to a division per capita or per stirpes is unimportant."17

In a very complicated unreported case ${ }^{\mathrm{x}}$ the chancellor, who adopted the theory of cross limitation was reversed upon appeal. The testamentary trust provided certain stock for the benefit of two of the decedent's daughters, giving one-half of the income to A during her lifetime and at A's death, if she leaves issue, then to such issue for a period of twenty years after her death. It was further provided that if A died before the testatrix leaving issue then the issue should take one-half of the income for a period of twenty years from the death of the testatrix. The will contained identical provisions for $\mathrm{B}$, another daughter. A codicil made identical provision for a third daughter $\mathrm{C}$, giving to her and to her issue onethird of the income, and cut down the gifts to $\mathrm{A}$ and $\mathrm{B}$ and their issue to one-third. In other words, the gifts to $\mathrm{A}, \mathrm{B}$, and $\mathrm{C}$ and their issue were upon identical terms and those terms were as stated in the will except the shares were diminished from one-half to one-third. The codicil expressly otherwise confirmed the will. The will which was so confirmed contained this direction for the division of the corpus which direction was not literally appropriate in the circumstances now that three daughters had been admitted:

It is my wish and will, and I hereby direct that when by the death of both of my said daughters, A and B without issue or if either of them has issue, then by the expiration of said period of twenty years herein mentioned, the purposes and objects of the foregoing provision for the benefit of said $A$ and said $B$ and their issue shall expire and be fulfilled then and as soon as convenient after the consummation of these events the entire net proceeds and balance of my said trust estate with all of its accumulated earnings and proceeds shall be distributed among my then surviving grandchildren, the children of all my sons and daughters and their heirs forever, share and share alike.

In the same clause the testatrix expressed the wish that the stock be not sold until the death of both daughters unless it be offered first to the

${ }^{17} 32$ I Ill. 368,377 , 15r N.E. 905 , 909 (r926).

${ }^{28}$ Trump v. Fitzpatrick, Appellate Court, First District, October Term, I934, No. 37843. This case was compromised and the appeal withdrawn after opinion rendered. 
sons. The testatrix left surviving her three sons, four daughters and nine grandchildren. Daughter $\mathrm{C}$ had four children, one son had one, another son two and a daughter not a beneficiary of the trust had two. Daughter A died without issue and the question was, what should be done with the income. The lower court held that it should be divided between $\mathrm{B}$ and $\mathrm{C}$ and their issue until twenty years after the death of the survivor of the two who should leave issue. The fact was that $B$ had no issue and was past childbearing age. The effect of the decree was to give the children of $\mathrm{C}$ the whole income of the fund, and the income was large, for a period of twenty years following the death of their mother, and this to the total exclusion of five grandchildren of the testatrix. This feature of the case no doubt influenced the appellate court. In addition to this result, which might or might not be important according to one's theory of construing wills, great stress was placed both in briefs and in the oral argument upon the fact that the testatrix had limited each of the three daughters to specific fractional shares of the income. The fractional limitation, it was contended, could not be disregarded nor could those cases in which the income had been given to two or more persons equally apply. Finally there was stressed the separable division of the corpus of the trust in point of time because twenty years from the death of each daughter could not expire at the same point of time. The will and codicil were obscure. In them there was certainly to be found the implication that the fund should be held intact throughout the life of the trust. Moreover a division of the corpus per capita would in itself help, so far as the cases go, to produce this result independently. Opposed to all this was the difficulty of finding that point of time when the trust should finally end. The decree below, permitted it to continue "until the termination of the said trust, which shall be twenty years from and after the death of the last of said two daughters of testatrix to die leaving lineal descendants her surviving." This term of the decree appeared to meet the practical situation, but if daughter $B$ should have children and should die soon after the decree such children would enjoy one-half of the income for forty years if daughter $\mathrm{C}$ survived $B$ by twenty years and left issue to live twenty more years. Again suppose $\mathrm{C}$ died soon after the decree (this actually has happened) leaving children; those children can enjoy one-half of the income as long as $B$ lives even though it is more than twenty years from the death of $C$. At the time of the hearing it appeared likely that $B$ would predecease $\mathrm{C}$ and this may account for what looked like a practical decree.

In a case of this character where the language of the will points about 
equally in different directions as well as in cases of ambiguity where there is no direction at all, the court is left to extract a meaning in accord with what it thinks the testator would have desired.9

\section{CONCLUSION}

In all of the cases so far considered the question of implied limitations arose upon the death of one or more takers of limited interest in the property. Such interests were invariably given for life and the gift over in the troublesome case was always in ambiguous terms. It is immaterial that the limited interests are in realty or in personalty or whether they are equitable or legal. The words used in such a case will give one result as well as another. If they be held to postpone the letting in of the future interest until the termination of the last of the particular interests in the property then cross limitations arise. This meaning, in spite of statements to the contrary, can not be used to justify a per capita rather than a stirpital division in remainder, because there is no practical or even legalistic barrier to overcome. A division per stirpes or per capita pertains to the quantum of division, never to the time when it is to be made. On the other hand, a determination to the effect that these words require a fractional letting in of the remainder precludes cross limitations from arising. This determination does have an important bearing upon the division in remainder more especially in cases where the remainder is given to a contingent class. In other words, it would be absurd to hold that a class described as "my then surviving grandchildren" following a gift to the testator's children for life should be ascertained as a single class to share per capita at different times. Even when the gift is a vested one to such a class the same reasoning would apply. Because of unborn persons the members of the class would be different at different times.

If what has been said in the preceding paragraphs is true it must also follow that a determination in favor of a per capita division to a class in remainder requires the ambiguous words to be interpreted in favor of a single point of division upon the termination of the last of the preceding limited interests with the consequent implication of cross interests to the

${ }^{9} \mathrm{Mr}$. Justice Holmes, in Hall v. Hall, supra note 8 in passing upon the meaning of a direction to divide property "among all such issue or children, share and share alike" said: "We agree that the great reasonableness of a different disposition, or a consideration of what is likely, on general principles, that a testator would have wished, cannot be allowed to change the interpretation of the words and of the meaning is plain apart from such considerations. But we have reached the opinion, although not without hesitation and doubt, that a meaning more likely to meet what the testator would have desired than either of those suggested can be extracted from the words themselves" (p. 27o). 
takers of preceding estates in the property. On the other hand, a determination that remaindermen take per stirpes impels no such result.

If it be assumed that the mode of division of the remainder should control the implication of cross limitations then, in the case supposed, they are made to rest upon an unexpressed intention, for the will is as silent about the mode of division in remainder as it is about the whole estate going over together. The contrariety of opinion of equally able courts upon the subject of distributions per capita or per stirpes generally shows this to be true. Reference alone to the cases already considered indicates this. ${ }^{20}$ The subtle distinction between the gift in remainder in the two following cases might appeal to the "legal mind," but it has no foundation in good sense and sheds no light upon the donor's intent: ( $I$ ) To my two children $A$ and $B$ for their lives, share and share alike, with remainder over upon their decease to their children; (2) to my two children A and B for their lives, share and share alike, with remainder over upon their decease to my grandchildren. Where A and B are the testator's only children he has designated the same identical persons to take in remainder. In the one case he has designated them in terms of relationship to himself; in the other by that to his children. In both the remaindermen take, if at all, by purchase and not by descent. As a class there is nothing to show that they are not all equally the objects of their grandfather's bounty. Yet in the majority of jurisdictions stirpital division will be decreed in the first case and probably not in the second. This may be explained, perhaps, upon the ground that a stirpital division is quite generally the rule of the descent statutes and this rule of division, with which the courts are more or less familiar, may impress them as inherently fair.

In final analysis it must be conceded that, in the case supposed, there is no particular reason for reaching one result rather than the other upon the point of implied cross limitations.

\section{B. ULTIMATE IIMITATIONS}

When either land or personal property is given to two or more persons for life, with a gift over to the issue of each life tenant absolutely of a share, coupled with a gift over of the share of each life tenant dying without

${ }^{20}$ Another class of cases in which courts have divided upon the subject of division per capita or per stirpes is where there is an immediate absolute gift "to the children of $A$, the children of $B$ and to $C$ in equal shares." Our supreme court departed from McCartney v. Osburn, II $8 \mathrm{III}, 403,9$ N.E. 2 IO ( 1886 ) in a series of cases beginning with Dollander v. Dhaemers, 297 Ill. 274, I30 N.E. 705 (r921) and running through Dahmer v. Wensler, 350 Ill. 23, I82 N.E. 799 (I932). It has very definitely committed itself in favor of division per stirpes in all cases. 
issue, to the surviving life tenants for their lives, and at their death to their issue, with an ultimate gift over absolutely on the death of all life tenants without leaving issue, courts imply cross limitations in favor of issue of life tenants although the parent or parents of such issue did not survive the life tenant who died without issue. The same result is reached when the donor in more summary manner gives over the shares of those dying without issue to the survivors in the same manner as their original shares were given. ${ }^{2 \mathbf{r}}$

In cases of this character the question of implied cross limitations ${ }^{22}$ arises only when a life tenant dies without issue predeceased by some other life tenant who left issue that now claim a share in the property. If there be but two life tenants in the case supposed or if the last of the life tenants to die leaves no children there is certain to be intestacy of a residuary gift upon a literal construction of the words "survivor" or "survivors." First the elaborate dispositions of a will of this character make it clear that the testator and his draftsman intended to guard against intestacy. Second, it must be apparent that no rational mind could want to withhold property from the issue of a person because that person did not happen to survive a co-life tenant and give it to them if their parent happened to survive. These two considerations standing alone have a bearing upon an intention not expressed in the will. In the mind of some courts notwithstanding these considerations the words "survivor" or "survivors" must be given effect because they are not at all ambiguous in their import. ${ }^{23}$ In the mind of other courts these considerations are enough and were so held to be by Mr. Justice Holmes in a case, ${ }^{24}$ which though subsequently criticized ${ }^{25}$ has been followed ultimately ${ }^{26}$ in Massachusetts. The difference between the two lines of authority goes to the heart of the interpretive process, or, more accurately to what courts are willing or un-

${ }^{2 r}$ Harman v. Dickenson, I Brown Ch. Cas. 9I (I87I). For a wide collection of English cases see Harrison v. Harrison, [1902] 2 Ch. 136.

22 If cross limitations are implied here they would, if translated, read as follows, assuming but two life tenants, $A$ and $B$ : Upon the death of $A$ without issue, the share from which $A$ received the income shall be and become the property of B's issue. There would be an identical limitation of B's share in favor of A's issue. If there were more than two life tenants, the number of cross limitations would increase accordingly.

${ }_{23}$ This appears to have been finally settled in England by the House of Lords, Inderwick v. Tatchell, [1903] A. C. x20.

${ }_{24}$ Balch v. Pickering, $x_{54}$ Mass. 363,28 N.E. 293 (r8gr).

${ }^{25}$ Lawrence v. Phillips, 186 Mass. 320, 7 I N.E. 54 I (xg04).

${ }^{26}$ Boston Safe Deposit \& Trust Co. v. Nevin, 21 2 Mass. 232, 98 N.E. Io5I (Igr2); Wentworth v. Bell, 249 Mass. I20 I44 N.E. Io2 (rg24). 
willing to do when the words used by a testator produce a result he would not want.

When in addition to the two circumstances mentioned above there is a gift over upon the entire failure of issue to the life tenants all courts would agree that the logical inference from this clause is a gift to the issue of the life tenants whether such issue be of survivors or not. The condition upon which the ultimate gift over is predicated, i.e., the total failure of issue negatives its taking effect if there be any issue at all. Consequently there is expression enough in the will to destroy the meaning of the words "survivor" or "survivors" or perhaps create a conflict of meaning in which those words are rejected. But it should be noted in passing that in the mind of many, if not most courts, no inference at all of a gift to issue is to be found in a gift "to A for life and if he dies without issue to B in fee" even where the refusal to so infer a gift results in intestacy. ${ }^{27}$ It is clear of course that in the class of cases here considered there is much more than a mere ultimate gift over to support that inference.

In this state there appears to be only one reported case of cross implication of ultimate limitations. ${ }^{28}$ Here the testator gave all his residuary estate in thirds to his three named grandchildren for their lives with remainder over to the issue per stirpes of each grandchild of his or her third. In case one or more grandchildren should die without issue then the survivor or survivors of the grandchildren should take the share or shares of the one or of those so dying. Then followed a final clause which read as follows: "and I further provide and direct that in case of the death of all three of said last named grandchildren without either of them leaving such issue or descendants of issue them surviving, then all of said estate hereby provided for such last named three grandchildren shall descend to my son John H. Witbeck and his heirs-at-law." Upon the death of one of the three grandchildren without issue the court was called upon to construe the will. It held that the two surviving grandchildren took one-third of the real estate, upon a determinable fee subject to devestiture on death without issue in favor of the survivor. In other words, the accrued share or shares were subject to the same limitations as the original shares. If all should die without issue, only then would the ultimate gift over take effect. If the grandchild to die last should die without issue and there were issue of a predeceased grandchild living then those issue should take.

${ }^{27}$ See Bond v. Moore, 236 Ill. 576, 86 N.E. 386 (1908). This is the leading case in Illinois upon the subject of implied gifts generally. It has been consistently followed in later cases with the result that implied gifts are not common.

${ }^{28}$ Lombard v. Witbeck, I 73 IIl. 396,5 I N.E. 6r (r898). 
Thus there were cross gifts of a fee by implication in favor of the issue of each grandchild of the share of any grandchild who died without issue and this would be true as to both original and accrued shares. ${ }^{29}$

It is important to note that this case differs from all the cases heretofore discussed in that there is no direct gift to the issue of any grandchild of an accrued share, but only of primary shares. The absence of this feature of the gift destroys any argument that might be founded upon the absurdity of a gift to issue made to depend upon the survivorship or nonsurvivorship of their ancestors. On the other hand, the absence of that direct gift in terms in which it is found to exist in the other cases eliminates the necessity for rejecting those unambiguous and troublesome words "survivor" or "survivors." The ultimate effect of the case is this: When the ultimate gift over is to take effect only on the total failure of issue to all the life tenants and when those issue are given remainder interests in fee in the original shares, there is no reason they should not take the fee under the circumstances here considered.

CONCLUSION

In the implication of ultimate cross limitations all of the cases show that the courts are really concerned with logical inferences to be drawn from the words of the will, i.e., with interpretation in its true sense. Whether such gifts should be freely raised or not is something about which courts may differ. Even if there be agreement in this, the logical force of the inference is so dependent upon the wording of a particular will that no clear line can be drawn between the decisions of courts which profess to take opposing views. ${ }^{30}$

29 For later cases involving the same will and showing the difficulty of determining exactly what the principal case decided, see: Aloe v. Lowe, 278 Ill. 233, Ir5 N.E. 862 (IgI7); same, 298 Ill. 404, I3I N.E. 612 (I92I); same 230 IIl. App. 538 (I923).

${ }^{30}$ The Illinois supreme court has said that implied cross limitations will not be created in a deed. Whittaker v. Porter, 32I Ill. 368, 372, I5I, N.E. 905, 908 (I926). 